\title{
The conqueror motif in chapters 12-13: a heavenly and an earthly perspective in the Book of Revelation
}

\author{
E C Shin ${ }^{1}$
}

(University of Pretoria)

\section{ABSTRACT \\ The conqueror motif in chapters 12-13: a heavenly and an earthly perspectives in the Book of Revelation}

The theme of the conqueror motif in the book of Revelation is one of the prominent themes. The theme of the conqueror motif provides various symbolical messages from an exegetical and theological perspective. An alternative symbolic perspective provides a heavenly perspective and the symbolic transformation. Various images such as salvation for the conquerors and judgment of the evil ones, or victory of the Lamb and defeat of Satan, transform our earthly perspective into the heavenly perspective, and give us a new understanding as to how the conquerors should see the world. To provide the conquerors with a new understanding is to give them a reversed effect as a marginalized group and to reveal deep spiritual conflict between God and Satan. Who is in control in history? With the result of the heavenly war between Michael and the dragon in 12:7-9, John proclaims the victory of God, who is the real conqueror, and provides the heavenly perspective that God is in control of the cosmos, as well as of history.

\section{INTRODUCTION}

According to Beasley-Murray (1992:191), chapters 12-13 are a central part of the Book of Revelation. Kistemaker (2001:351) also explains these chapters as a central section. In order to reveal the theological message about the conqueror motif within this section, the interaction of different historical and literary aspects, like heaven and earth, or above and below, should be surveyed. Whereas in 11:15-19, the kingdom of God given to the conquerors is proclaimed in the light of a heavenly (above) aspect, Revelation 12-13 introduce the defeat of Satan and the two beasts, highlighted by the verb cast out ( ${ }^{\prime} \beta \lambda \eta \dot{\theta} \theta \eta$ ). The heavenly (above) and earthly (below) perspectives in chapters 12-13 reveal the heavenly reality of who the conquerors

1 Post-graduate student of Prof J G van der Watt, Department of New Testament Studies, University of Pretoria. 
are. Through the heavenly perspective of chapters $12-13$, the author of Revelation wanted to reveal the ultimate sovereignty of God and the real identity of the conquerors (Gilbertson 2003:83). By providing the contrasting image of heaven and earth, Bauckham (1993b:90-91) gives us the real identity of the conquerors and the defeated. That is the rhetorical power unmasking the heavenly and earthly reality in its many forms.

The Book of Revelation can be understood as revealing hidden dimensions of the world and transcendent realities of the universe (Thompson 1990:31). The interplay of heavenly and earthly points of views is used as rhetorical communication by John to deliver his prophetic message through the contrasted image. The point of view provides a new perspective that guarantees the victory of God's people during their present crisis. In terms of spatial and temporal horizon, Gilbertson (2003:84) comments on the heavenly perspective as follows:

This heavenly perspective enables him to discern the true nature of earthly events. ... The expansion of spatial horizons has the effect of unmasking reality, of revealing the divine hand at work and exposing the nature of evil in its many forms.

Bauckham (1993b:88-94) also suggests that the heavenly perspective answers the question of who the real conquerors are, because the heavenly perspective breaks the earth-bound delusion of the evil trinity, namely the Dragon, the sea beast, and the earth beast. Therefore, the heavenly perspective reveals that the everyday reality of people should be considered in order to understand John's narrative world that he wanted to present to his audiences or readers.

\section{THE CONQUEROR IN REVELATION}

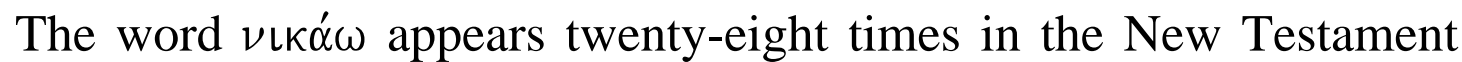
(cf. Moulton and Geden 1978:665-666) ${ }^{2}$; seventeen in the book of Revelation. Almost half of them are introduced in the seven letters commonly referred to as the conqueror statement. But, when we deal with the use of conqueror ( $\nu\llcorner\kappa \alpha \omega)$ ), it is necessary to investigate the meaning of conqueror in terms of its biblical, socio-historical, and

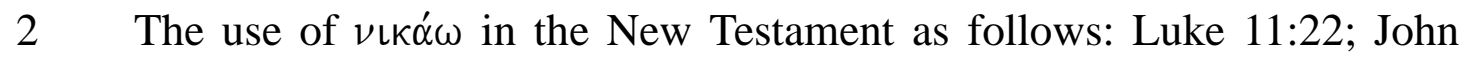
16:33; Romans 3:4; 12:21 (x2); 1 John 2:13, 14; 4:4; 5:4 (x2), 5; Revelation 2:7, 11, 17, 26; 3:5, 12, 21 (x2); 5:5; 6:2 (x2); 11:7; 12:11; 13:7; 15:2; 17:14; 21:7. 
cultural situation because the demand over conquest is closely linked with these situations.

In the New Testament, we can find out the $\nu$ เк- word group

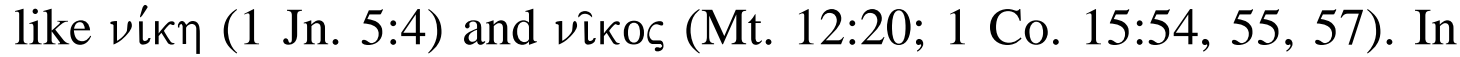

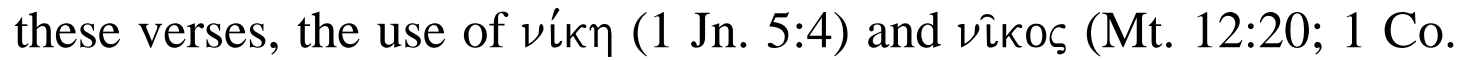
$15: 54,55,57)$ have the same meaning as $\nu \iota \kappa \alpha \omega$. The word group noted above implies "victory" or "superiority," whether in the physical, legal or metaphorical sense, whether in moral conflict or peaceful competition (Bauernfeind, 1967:4.942). Louw \& Nida (1993:501) are of the opinion that "the closest equivalent of 'to be victorious over' is to defeat".

Nıк $\alpha \omega$ in the New Testament can be used for different objects.

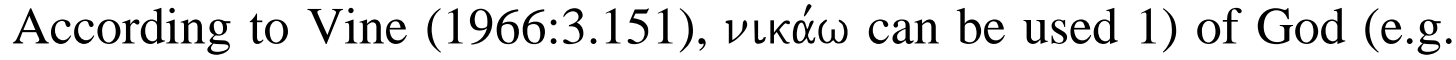
Rm. 3:4), 2) of Christ (e.g. Jn. 16:33; Rev. 3:21; 5:5; 17:14), 3) of his followers (e.g. Rm. 12:21b; 1 Jn. 2:13, 14; 4:4; 5:4-5; Rev. 2:7, 11, 17, 26; 3:5, 12, 21; 12:11; 15:2; 21:7), 4) of faith (e.g. 1 Jn. 5:4), 5) of evil (e.g. Rm. 12:21), 6) of predicted human potentates (e.g. $6: 2 ; 11: 7 ; 13: 7)$. The different uses of conqueror through Revelation imply that when we regard the conqueror motif, it must be understood in its own contexts. That is why the promise statement and fulfillment statement given to the conquerors through the texts are introduced with a different perspective.

Of the seventeen, seven (e.g. 2:7, 11, 17, 26; 3:5, 12, 21) are closely related to exhortations and promises given to the conquerors of the churches conquering their own situations. In these situations, the use of 'o $\nu \iota \kappa \hat{\omega} \nu$ ( $\tau \hat{\omega} \nu \nu \kappa \hat{\omega} \nu \tau \iota)$ as the substantival participle implies a continuing characteristic of the conquerors, (Beale 1999:271) struggling for victory because the participle in Greek emphasizes the continuous characteristic. Thus, the exhortations and promises given to the conquerors through chapters 2-3 are provided to those who really were conquerors as the people of God.

An interesting thing that occurs in the seven letters is the change between the final two statements of the letters. In the first

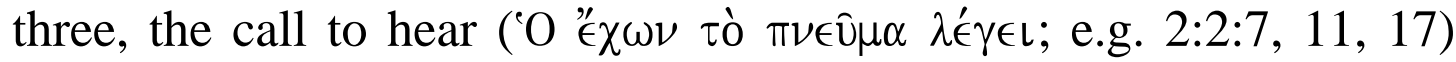
precedes the promise statement given to the conquerors (T⿳亠丷厂 $\nu\llcorner\kappa \hat{\omega} \nu \tau \iota$ or 'O $\nu\llcorner\kappa \hat{\omega} \nu$; e.g. $2: 7,11,17)$. And, in the last four letters, the promise statements given to the conquerors , $\mathrm{O} \nu\llcorner\kappa \hat{\omega} \nu$; e.g. 2:26; 3:5, 12,21 ) precedes the call to hear ( $O{ }^{\prime \prime} \in \omega \nu \ldots$ to. $\pi \nu \in \hat{\nu} \mu \alpha \lambda^{\prime} \epsilon^{\prime} \gamma \in \mathrm{L}$; e.g. 2:29; 3:6, 13, 22). According to Bauckham (1993a:10), it may be 
that the author's intention to divide with three and four patterns is simply to differentiate these three and four patterns as distinct from the three series of seven judgments. Kistemaker (2001:118; cf. Duff, 2001:31-35) is also of the opinion that "the first part of this sentence is an idiomatic expression and refers to the capability of a person to hear and an accompanying willingness to listen. The second part is a command to listen attentively and obediently to the words of the Holy Spirit”.

Two references in 5:5 and 17:14 are connected with the conqueror, Christ. Here, the victory of Christ is ironically based on the blood of the Lamb, accomplished through his death on the cross. In the case of $17: 14$, even though the victory of Christ will be in the future, the reason for victory is also based on the blood of the Lamb (Reddish, 1982:133-136). Just as the theme of conqueror applied to the people of God by keeping the word of God and enduring unto the death, Christ is the conqueror par excellence through his death (Strand, 1990:237-254).

\subsection{Keeping the Word of God and endurance}

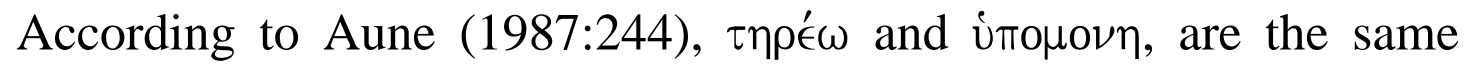
words as $\nu \iota \kappa \alpha \dot{\omega} \omega$. But these words are "a passive experience"

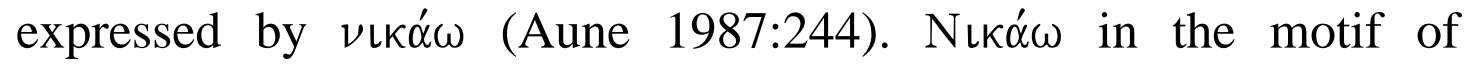
conqueror can be interchanged with other words that imply the meaning of victory. Of these, $\tau \eta \rho \epsilon \omega$ and $i \pi \circ \mu о \nu \eta$, are the prominent

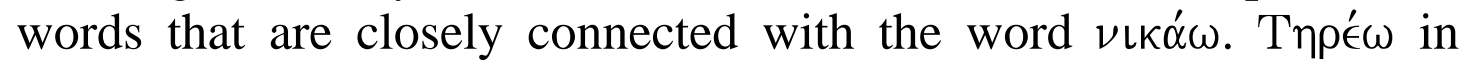
Revelation appears eleven times (e.g. 1:3; 2:26; 3:3, 8, 10 (x2); $12: 17 ; 14: 12 ; 16: 15 ; 22: 7,9)$. The contexts in which they are used are closely related to the conquerors as the people of God. One of the prominent examples is 2:26. Christ promises to give authority

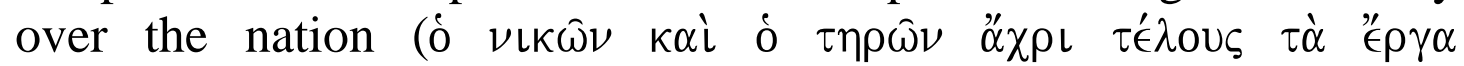

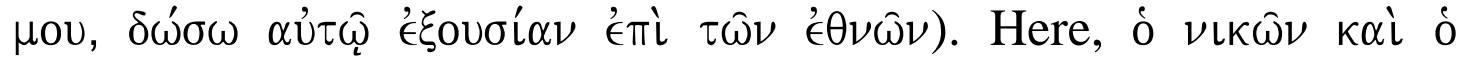
$\tau \eta \rho \hat{\omega} \nu$, which are linked with a coordinating conjunction $\kappa \alpha$, are used together to do the work of Christ (Gilbertson 2003:112-113).

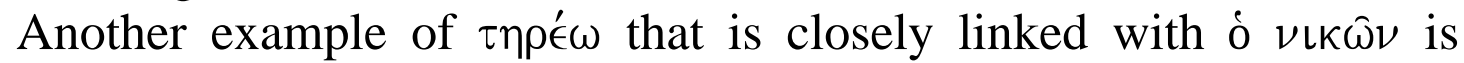
introduced in 14:12. The saints, the other expression of the conquerors, are those who kept ( $\left.\tau \rho^{\prime} \epsilon\right)$ ) the commandment of God and the faith of Jesus (Kistemaker 2001:344-345).

Y rouov $\eta$ (endurance) also has the passive meaning of word

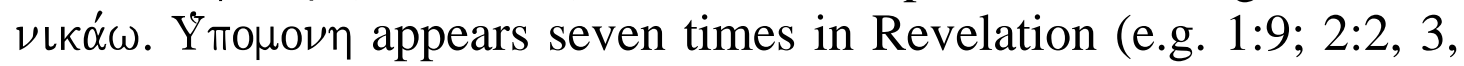
19; $3: 10 ; 13: 10 ; 14: 12)$. In these contexts, the imouovๆ provides the 
expression of behaviour of the Christians, namely conquerors who suffered at the hands of the wicked ones. That is why imouov $\eta$ is connected with other words that show the meaning of conquest or victory, like keeping the name of Christ, faith, the word of God, tribulation (Boring 1989:96). In the seven messages, endurance

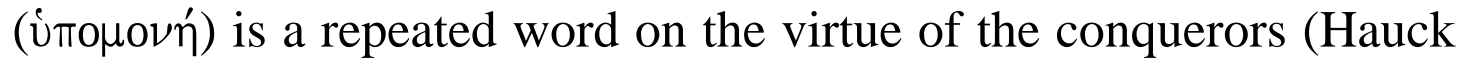
1967:4.588). It will also be the "final and supreme test of faith" (Hauck 1967:4.588). One of the prominent examples is 13:10 in

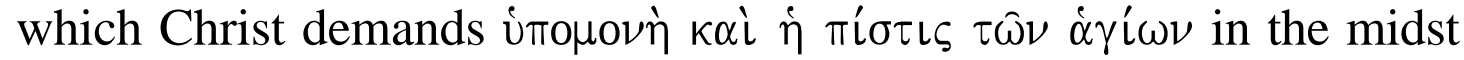

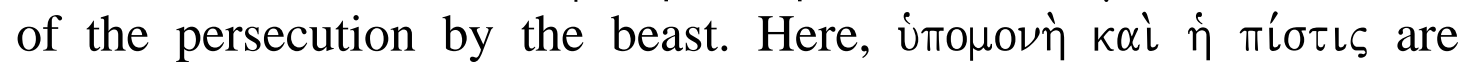
introduced with the lists of the saints as the conquerors.

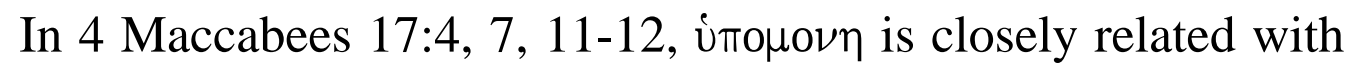
the faithful people of God who keep the commandment of God. The word umouov $\eta$ is given to the people of God who suffered under the persecution to maintain their faith and relationship with God (cf. Louw \& Nida 1993:308). That is why the people who kept God's commandments and endured persecution can be called conquerors.

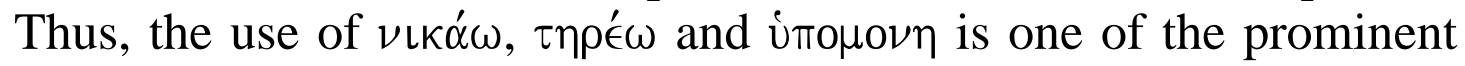
examples that show the theme of victory in terms of conqueror motif in Revelation (cf. Aune, 1997:75-76).

\section{APOCALYPTIC SYMBOLS IN CHAPTERS 12-13}

It is accepted that Revelation 12-13 is one of the most important chapters (Collins 1976:231) in revealing the motif of victory and judgment through the contrasting image of a heavenly and an earthly framework. When we consider chapters 12-13 within the structure of the book of Revelation, chapters 12-13 show us a great cosmic conflict between God and Satan that evokes a powerful symbolic image through a dynamic framework (Beasley-Murray 1992:191-197).

The hymn of victory in 12:10-12, forming the central verses in this section, is proclaimed to praise God and Christ as the main characters. In terms of micro and macro structure, this section demonstrates the final victory of God and conquerors as a future perspective that will be accomplished in 20:1-15, as well as the detailed interpretation of the previous section in chapter 11:15-19. While chapters 12-13 start with a new section, beginning with $\kappa \alpha i$

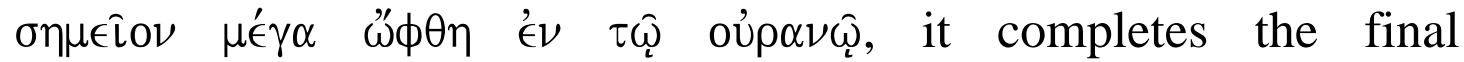
eschatological judgment and salvation in chapters 20-22 (Mounce 1977:234) that have a unified framework characteristic of inclusion. 


\subsection{Theophany formula}

One of the characteristics dealing with final eschatological salvation and judgment in Revelation chapters 12-13 is the theophany formula, expressed as flashes of lightning, rumblings, peals of thunder, an earthquake and a great hailstorm (e.g. 4:5; 8:5; 11:19; 16:18-21). These eschatological phenomena indicate the presence of God to execute salvation and judgment in connection with the Old Testament (e.g. Ex. 19:16; 20:18), where we hear echoes of salvation and judgment. According to Bauckham (1993a:201), the scene that shows the final eschatological event expects the coming of God as King and Judge, who gives eventual salvation to the conquerors and executes his final judgment on the people of Satan (cf. Beale 1999:618).

The examples of the theophany formula are introduced in 4:5; $8: 5 ; 11: 19 ; 16: 18$. This formula appears in different places in Revelation, for example at the throne (4:5), from the altar (8:5), and from the temple $(11: 19 ; 16: 18)$. All these things are closely connected with the heavenly temple in which God's divine salvation and judgment are executed and where the heavenly perspective is provided. To the first-century Christians, who would have been familiar with the reality of temple as the place of God's presence, the image of temple might provide both transcendence and transformation in terms of the heavenly perspective that the conquerors will have (Stevenson 2001:220). This theophany formula, based on the rhetorical and social situation the first Christians faced, provides the transformation of their viewpoint and a new divine understanding. That is, the image of theophany formula provides a symbolic picture to look at this world from "God's kingship" (Poythress 2000:101), requiring new understanding and a new point of view. As Stevenson (2001:231) argues, this revelation displays this world from a heavenly point of view and the reality that Christians faced in the Roman Empire. Therefore, this kind of heavenly perspective provides a clear boundary between God and his people and Satan and his followers.

Then, who are the people of God, the conquerors? The prophetic message of Revelation is very clearly seen in the light of a heavenly perspective. Some Jewish communities and even some Christian members have joined with Satan through compromise and assimilation with the Roman Empire. Self-sacrifice, receiving harsh 
treatment, faithfulness in keeping the word of God (cf. 1:3, 9; 2:25; $3: 10 ; 12: 17 ; 22: 7$ ) and suffering unto death (cf. 2:2-3, 13, 19; 12:11; $13: 10 ; 14: 12$ ) are the true attributes of God's people as the conquerors. They maintain a heavenly perspective in contrast with an earthly perspective. While the oppressed people of God as the conquerors experience the transformed universe and the newly understood heavenly perspective (De Smidt 1994:231), the people of Satan are involved in a three judgment series as the object of God's judgment (Mounce 1977:231).

\subsection{Heavenly war between the conqueror and the defeater}

Chapters 12-13 reveal a heavenly dimension of how the conquerors won the victory and how the people of Satan received the judgment from God. This is explained by using intense interaction between the heavenly and earthly perspectives in order to unmask the true nature of events (Poythress 2000:133-134). These divine war events provide throughout chapters $12-13$ a heavenly perspective on the earthly reality, namely that victory will be attained in the end. The meaning of the heavenly perspective is to transform our earthly perspective into the heavenly perspective (Gilbertson 2003:84) and to give us a new understanding to how Christians should see the world they experience now. In Revelation, this element has a reversed effect at times (cf. Thompson 1990:42-43).

The characteristics of chapters 12-13 are, indeed, evaluated as including the final judgment against the evil ones in chapters 19-20. In chapters $12-13$ and $19-20$, the prominent theme of victory or salvation and judgment or defeat frequently appears in conjunction with combatant terminology between God and Satan. The story of God and Satan in chapters 12-13 and 19-20 can be paralleled as the same symbolic story in terms of victory and judgment, focusing on the victory of God/his people and the judgment of Satan/his followers (see Shea 1985:37-54). According to Poythress (2000:64), the structural parallel of chapters 12-13 and chapters 19-20 can be suggested as follows:

A. The people of God depicted with the imagery of light and creation (12:1-2)

B. The Dragon, Satan (12:3-6)

C. The Beast and the False Prophet (13:1-18)

C.' The Beast and the False Prophet are destroyed (19:11-21)

B.' The Dragon is destroyed (20:1-10)

A.' The people of God in the imagery of light and creation (21:1-22:5) 
The above structural parallel shows, according to Poythress, the final victory of the people of God in terms of the new creation and the total destruction of the dragon, the beast, and the false prophet.

As noted above, very significant words used throughout

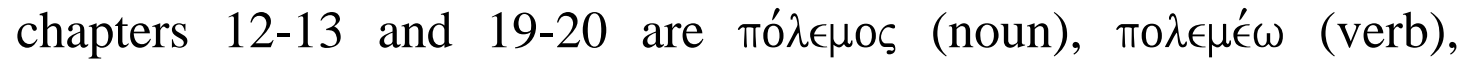
implying "military as well as juridical symbol” (Leivestad 1954:219).

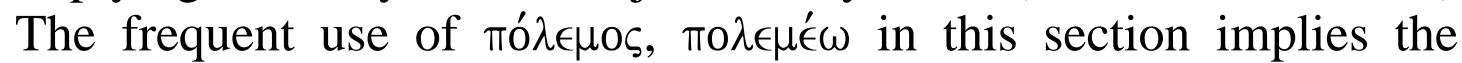
combat between God and Satan, highlighted by the defeat of Satan (Kistemaker 2001:353). The words of these various wars (mó $\lambda \in \mu \circ \varsigma$, $\pi 0 \lambda \in \mu \epsilon^{\prime}(\omega)$ in chapters 12-13 and 19-20 reveal that the war between God and Satan is the prominent present reality (Mounce 1977:243) to show who the real conquerors are in the light of eschatological salvation and judgment perspective. That is why the author of the book of Revelation delivers some encouragement and hope to those who were in need of being encouraged on the basis of their discouraged situation (cf. Beasley-Murray 1992:191-197).

The result of this war, as we know through the use of these words ' $\epsilon \beta \lambda \eta^{\prime} \theta \eta$, $\epsilon \beta \lambda \eta^{\prime} \theta \eta$, $\epsilon^{\epsilon} \beta \lambda \eta^{\prime} \theta \eta \sigma \alpha \nu$ (aorist, passive of $\beta \alpha \dot{\alpha} \lambda \lambda \omega$ : cf. 12:10, 13; 19:20; Kistemaker 2001:353) in 12:9, is the defeat of Satan and his followers. That is, also their defeat and judgment are highlighted by the use of these verbs ${ }^{\prime} \beta \lambda \eta^{\prime} \theta \eta$, ${ }^{\prime} \epsilon \beta \lambda \eta^{\prime} \theta \eta$, ${ }^{\prime} \beta \lambda \eta \dot{\eta} \theta \eta \sigma \alpha \nu$ in $12: 9$, as well as of these verbs ' $\epsilon \beta \lambda \dot{\eta} \theta \eta \sigma \alpha \nu$ in 19:20 and ' $\epsilon \delta \eta \sigma \in \nu$ in 20:2. The casting down from heaven and their limitation to the earth in chapter 12:8, 12 describe their ultimate judgment in terms of spatial dimension (cf. Gilbertson 2003:100-102). Through the use of these words, we can suppose that ' $\epsilon \beta \lambda \eta^{\prime} \theta \eta$, ' $€ \beta \lambda \eta \dot{\theta} \theta \eta \sigma \alpha \nu$ (to throw away) and ' $\epsilon \delta \eta \sigma \nu$ (to bind) indicate the victory of Christ and the conquerors against the evil forces as a passive meaning (Aune 1998a:527-528, 695). That is, the words like ${ }^{\epsilon} \beta \lambda \eta \dot{\eta} \theta \eta$, $\epsilon \beta \lambda \eta \dot{\eta} \theta \eta \sigma \alpha \nu$ (to throw away), "' ${ }^{\prime} \delta \eta \sigma \in \nu$ (to bind),

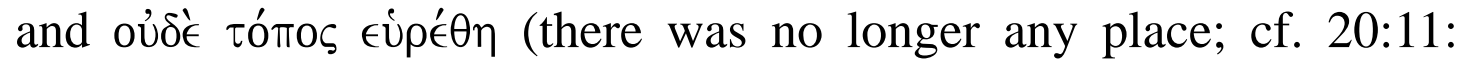

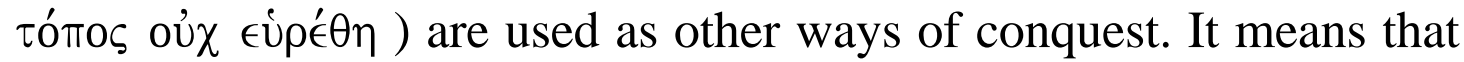
God has thrown out and conquered Satan and his followers from heaven, and God has established his kingdom (cf. 11:15),

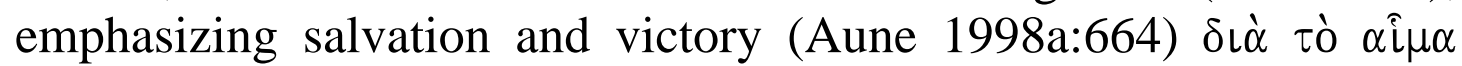

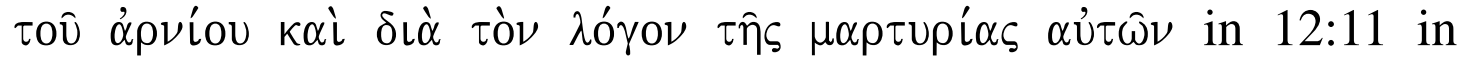
terms of active meaning. Therefore, the thematic parallelism above, suggested through chapters 12-13 and the interrelation within chapters 19-20, depict two kingdoms of war between God's kingdom and Satan's kingdom. It establishes a well-constructed cosmic divine war story in terms of victory and judgment and climaxes with the 
victory of Christ who becomes the real conqueror through the death on the cross (Harrington 1969:167-172).

\subsection{The conqueror, the victim}

The prominent example of symbolic transformation is the image of the lion of the tribe of Judah, the root of David, which was the traditional messianic expectation. But these titles lion of the tribe of Judah and the root of David are reinterpreted by the slain Lamb (Michaels 1992:131; cf. 5:5-6) and introduced as conqueror. Through this symbolic transformation, this picture provides a powerful message in conjunction with the question of the conquerors. It indicates that the victory of the Lamb is not connected with the overthrowing of enemies by military or political power, but his own self-sacrifice on the cross (Michaels 1992:137). According to Aune (1997:352), the figure of the Lamb can be interpreted as the conquering Messiah and the atoning sacrificial victim, which has a transformed symbolic meaning. That is, the conqueror is the victim through his self-sacrificial death (cf. Barr 1984:39-50).

In chapters $12-13$, the point of view ${ }^{3}$ provides a contrasting image of heaven (above)/earth (below) to give God's point of view. John's narrative world, however, is explained beyond the surface meaning of this section in the light of the heavenly (above) perspective (Du Rand 1997a:258-259). It is John's narrative meaning that his beliefs, values, and points of view lead the audience/readers to recognize behind the situation of everyday life, the world of ultimate reality through the contrasting point of view (cf. Thompson 1990:41). Events that happened on earth must be regarded from another perspective, that is the heavenly or above perspective (cf.

3 Upensky's (1973:8-100) point of view can be classified into four separate planes: ideological, phraseological, spatial and temporal, and psychological. The ideological point of view refers to the normative system of the narrator that shapes the work. This point of view may be the author's point of view, value, norm, and the worldview. The phraseological point of view is described as an expression of speech in the level of words and diction. The spatial and temporal point of view is heard in terms of space and time provided in the narrative story. This point of view adopted by the author reveals the settings, characters, events, and process of time in the narrative story in order to give a clearer narrative perspective. The psychological point of view focuses on an individual consciousness through the action and speech of the characters in the narrative story, indicating emotions, thoughts, and perceptions. 
Caird 1966:153-154; Barr 1984:41; Resseguie 1998:48). As Gnatkowski (1988:96) comments, images of contrast in Revelation demand the choice of the reader between God and Satan and provide the heavenly view about the real world in the symbolic world of Revelation. In this present situation, the most urgent message to his reader/audience is to see the contrasting image between God the Creator, as the sole object of worship, and the Roman Emperor, as the pretentious counterpart (Barnett 1989:112). Hence, John's symbolic world accomplishes the remarkable symbolic transformation through the contrasted images of heaven (above) and earth (below), and of visible and deep structure ${ }^{4}$.

In 12:11, we encounter the saints as the conquerors to whom Satan is opposed. In this verse, we have the other symbolic transformation that the conquerors are none other than the victims. Through chapter $12: 9-11$, the scene of victory or salvation is proclaimed in heaven and reveals the conquerors as follows:

\begin{tabular}{|l}
$\longrightarrow$ A (12:9): Satan (dragon) hurled down \\
B (12:10): Proclamation of victory/salvation in heaven \\
A' $^{\prime}$ (12:11): The Conqueror, and the victim
\end{tabular}

What makes the saints conquerors? The basis of the victory of the saints depends on 'the blood of the Lamb and the word of their testimony' that are closely linked with 6:9, 7:14, and 20:4. The reference regarding the blood of the Lamb can be connected with 7:14 (cf. 5:9) that "they have washed their robes and made them white in the blood of the Lamb”. The reference 7:14 that is linked with 144,000 describes the conquerors through the blood of the Lamb. This verse also encounters a symbolic transformation and a “striking paradox" (Mounce 1977:174).

The interesting thing is the mentioning of salvation through the word of their testimony. This passage is closely linked with 6:9 and 20:4 in that it has similar lexical and thematic correspondence (Aune

4 In Revelation, the image of contrast is one of the important literary patterns. Contrast associates things that are dissimilar or opposite (cf. Powell 1993:32-33). Through the image of contrast, the implied author can reveal the meaning of the text. For example, John uses the heaven (above)/earth (below) point of view (between chapters 2-3 and 4-5) that contrasts ultimate reality between theological confidence with present experience. 
1998a:406). A similar lexical and thematic correspondence of these

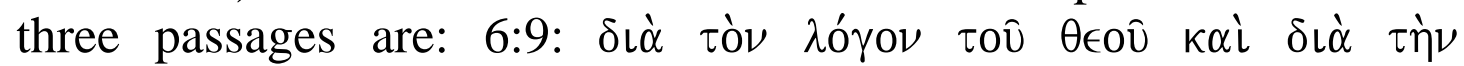

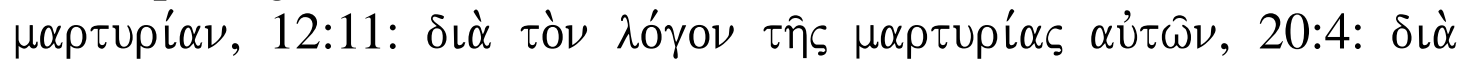

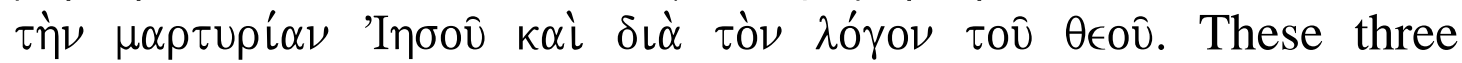
passages are given to the souls who are in heaven (Gourgues 1985:679). These images provide a heavenly (above) perspective through which the first Christians must conquer as the conquerors. The souls under the altar that had been slain in 6:9 are dead because of the word of God and their testimony.

In 12:11 the basis of the saint's victory depends on the word of their testimony and in 20:4 the souls who had been beheaded are seen because of their testimony for Jesus and God. The word and testimony of Jesus and God make them martyrs (Aune 1998a:406). That is, the use of these same word clusters in these passages implies that the same group of people is in view (cf. Shea 1985:45-47). They are none other than the conquerors who died as victims at the hand of Babylon (Resseguie 1998:184; cf. 11:7-10). Therefore, the death of God's people is clearly a prominent theme to discern (Beale 1999:392) whether they belong to the people of God or the people of Satan. As Pattemore (2004:90-98) argues, their death is a result of their witness $(6: 9 ; 11: 7 ; 12: 11 ; 17: 6 ; 20: 4)$ and their victory is by means of this witness, which leads unto death. The idea that their victory is their death imparts a powerful symbolic transformation the conquerors are the victims.

\section{THE CONQUEROR MOTIF FROM A HEAVENLY PERSPECTIVE}

Generally, the heavenly point of view in Revelation reflects the context for earthly events because that context is often closely connected with the socio-political situation that makes the story meaningful (cf. Sweet 1979:16, 113-114). Consequently, spatial dimension between heaven and earth functions as the prominent element of the text, as well as a powerful tool created by the author (Van Eck 1995:129).

In Revelation, the heavenly point of view offers the overall framework for the movement and development of the plot to reveal the earthly reality (Gilbertson 2003:81). John divides his prophetic message into two aspects, those of heaven and earth. The reason why he divides his message into heaven and earth is to focus on the core of his prophetic message or theology to the audience. Therefore, the 
earth must be reinterpreted through heaven or vice versa. The doxology of 12:10-12 concerning Christ and the conquerors emphasizes the reason of victory, as martyrdom by the blood of the Lamb and the word of the believers' testimony (Strand 1990:242243). The story flows into an earthly perspective again, that indicates a beast coming out of the sea (13:1) and the earth (13:11). The destiny of the beasts is decided with the appearance of the Lamb as the conqueror who stands on Mount Zion as the heavenly figure. It can be drawn as follows:

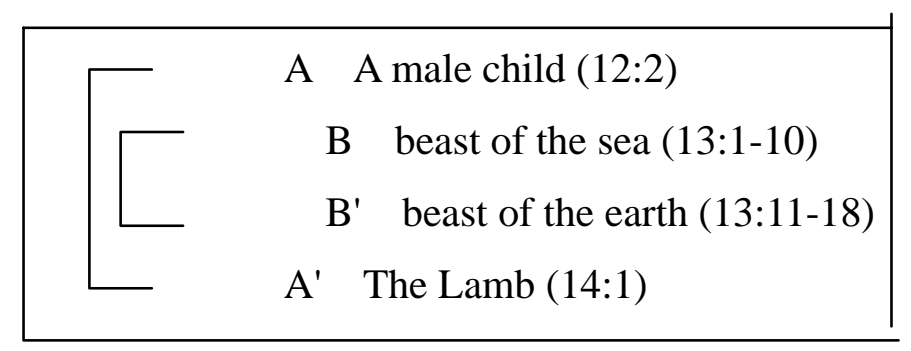

Through the diagram above, we can see that A and A', indicating the Messiah Christ and the Lamb, are the heavenly figures who will judge B and B', namely the sea beast and the earth beast. The scene of a male child, implying the exalted Christ in salvation history, in earthly perspective is changed into the scene of the Lamb standing on Mount Zion. Zion where the Lamb stands is introduced as the place of God's kingdom and of his presence to avoid God's woe, having a theological and eschatological meaning (Beasley-Murray 1992:221-222). An inclusion of A and A' in contrast with B and B', indicating the deceptive worldly power, supposes that the victory of Christ, the Lamb and the conquerors is confirmed in the heavenly perspective, as well as in the earthly perspective, against the sea and the earth beast (Du Rand 1993b:318-319). Therefore, we can find out the heavenly point of view of John that a male child and the Lamb as the conquerors will defeat the sea and earth beast and will win.

As we will see below, the contrasting response of these verses (12:10, 12:12, 13:3-4 and 13:10) shows us which side they belong to, namely the conquerors or the defeated. 


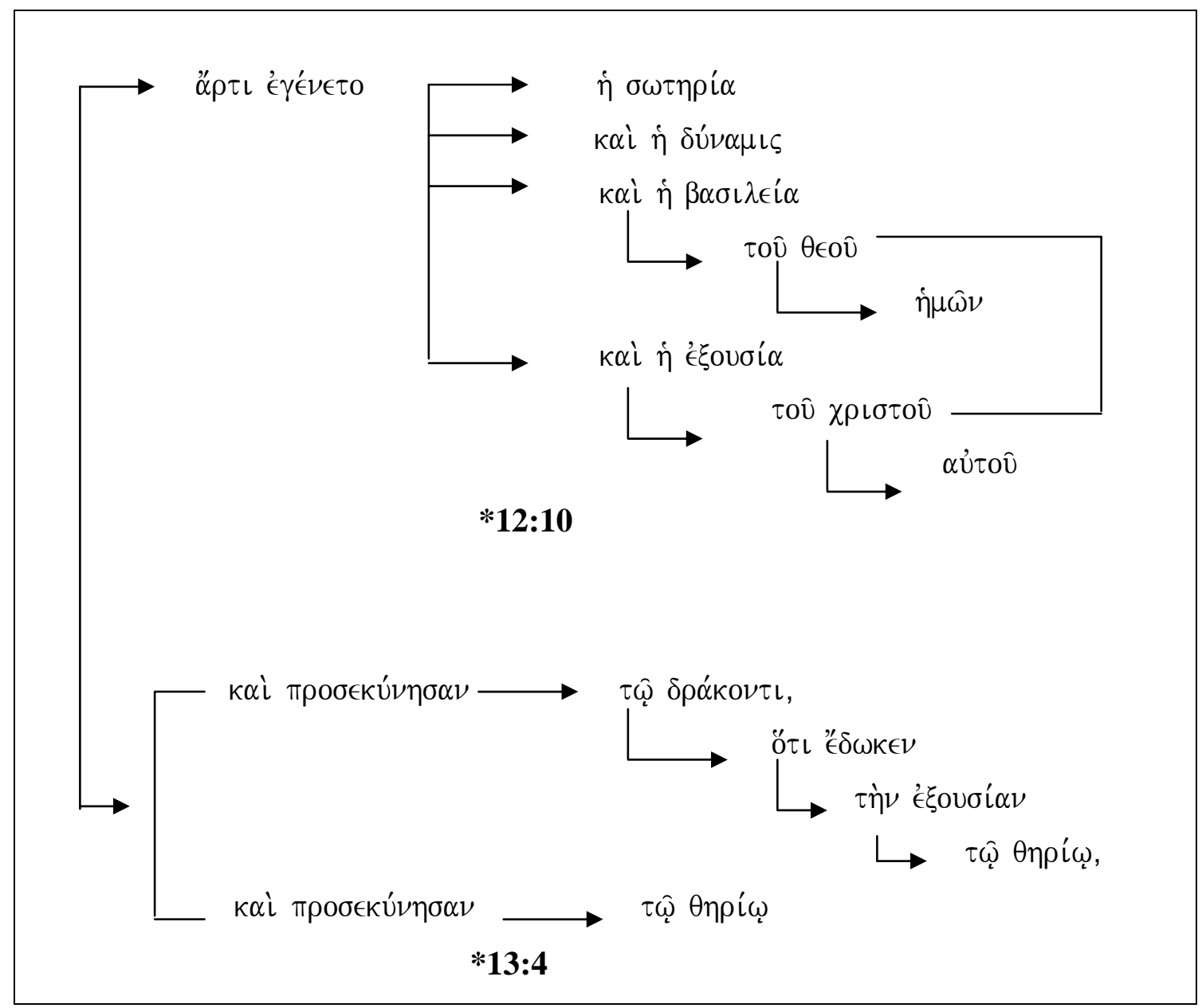

The contradictory feature of these two verses reveals the characteristics of God/Christ and Satan, and of the worshipper of God/Christ, along with Satan's worshipper the dragon. The conquerors who praise the works of God and Christ, and who recognize the ultimate reality, confirm the salvation, power, kingdom, and authority of God and Christ in heaven as well as on earth (e.g. 5:12-13).

The victorious hymn of God, Christ, and the conquerors in 12:10 are based on 12:7-9. The heavenly war between Michael and the dragon is reflected in 12:10-12 on the basis of Christ's sacrifice on the cross (Mounce 1977:243). The result of this war between Michael and the dragon has brought a different positive and negative psychological response. The establishment of God's kingdom and his sovereignty in heaven is expressed with the praise of God and Christ as the object of worship by people of God in contrast with the worship of Satan (Du Rand 1993b:316-317), personified as the 
Roman Emperor. This is a proper message in the context of the conflict situation between Christ and Caesar (cf. Aune 1987:243246). Therefore, those who praise the works of God and Christ might be called conquerors because they accept the salvation, power, kingdom, and authority derived from God against Satan. Even though they live in difficult circumstances enduring persecution, compromise, and self-deception, they recognize the ultimate reality of God and Satan. Through this hymnic composition, John provides the heavenly perspective that God is in control of the cosmos as well as of history (Lee 1998:192). As Witherington III (2003:34) insists, "the very heart of apocalyptic is the unveiling of secrets and truths about God's perspective on a variety of subjects, including justice and the problem of evil".

In contrast to the followers of God and Christ, the psychological response of the followers of the dragon and the beasts is to worship them with wondering admiration $\left({ }^{\prime} \theta \alpha \nu \mu \alpha \alpha^{\prime} \sigma \theta \eta\right)$ in 13:3. An interesting word $\dot{\eta} \hat{\epsilon} \xi$ ovo $\alpha$ is given to Christ and the beast. It shows us the characteristic of the beast's parody as evil force imitating God and Christ (Beale 1999:694). The diagram shown above implies that the source of their authority in the text is derived from God and the dragon respectively. According to DeSilva (1998:79-110), epideictic rhetoric, dealing with the topics of honour through praise and censure, reinforces virtues to the audience or reader in order to lead to honour and honorable remembrance after death. Only God and Christ can receive honour through the whole world. The first Christians had to have faith that God and Christ are in control of the whole world and they are the ultimate conquerors who should be worshipped. Consequently, the analysis above indicates that the right worship of God and Christ in contrast with its alternative, idolatrous worship of the dragon and the beast in a sociopolitical situation (cf. Botha 1988:87-98), had to be executed in the first Christian community to be called the conquerors (cf. Boring 1986:257-269).

\section{CONCLUSION}

Until now, I have described the conqueror motif in terms of the heavenly and earthly perspectives, focusing on chapters 12-13. When we understand the conqueror motif, an interesting thing is that it is dramatically expressed. To reveal the theme of conquest or 
victory and defeat or judgment, various symbolic images and transformations are suggested.

John provides two perspectives, namely the heavenly and the earthly perspectives. God's salvation and judgment are initiated upon the conquerors and the dragon, the beast of the sea, and the beast of the earth and proclaim the kingdom of God and the kingdom of the world. That is, the heavenly reality reinterprets the earthly reality that is dominated by the dragon, the beast of the sea, and the beast of the earth. The purpose of the heavenly perspective is to reinterpret how Christians should understand the earthly world they experience in pagan circumstances as the people of God (Barr 1998:4, 64-65, 104-105). That is why in chapters 12-13, the eschatological battle between Michael and Satan is introduced in terms of the heavenly perspective. In the light of the earthly point of view, the dragon and two beasts look like conquerors who

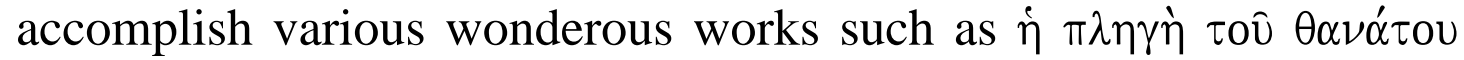

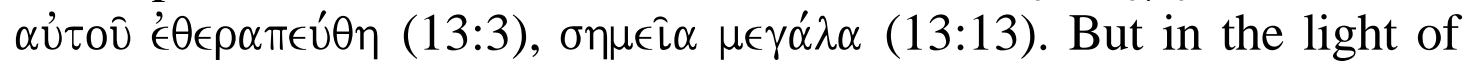
the heavenly point of view, they are the defeated. According to Caird (1966:153-154), the earthly reality can't be the same as the heavenly reality. In terms of the heavenly perspective, the real victory can be won by the blood of the Lamb unlike that of the dragon and two beasts (Boring 1992:715).

From a heavenly perspective, we should recognize that to keep and to hold the word of God and the testimony of Jesus, and to trust the blood of the Lamb, are the way of victory and conquest of all the faithful saints as the conquerors under pagan circumstances.

\section{Consulted literature}

Aune, D E 1987. The New Testament in Its Literary Environment. Philadelphia: Westminster Press.

-, 1997. Revelation 1-5. WBC 52a. Dallas: Word Books.

-, 1998a. Revelation 6-16. WBC 52b. Nashville: Thomas Nelson Publishers.

Barnett, P 1989. Polemical Parallelism: Some further Reflections on the Apocalypse. JSNT 35, 111-120.

Barr, D L 1984. The Apocalypse as a Symbolic Transformation of the World: A Literary Analysis. Int 38, 39-50.

-, 1998. Tales of the End: A Narrative Commentary on the Book of Revelation. Santa Rosa: Polebridge Press.

Bauckham, R 1993a. The Climax of Prophecy: Studies on the Book of Revelation. Edinburgh:T \& T Clark. 
-, 1993b. The Theology of the Book of Revelation. Cambridge: Cambridge University Press.

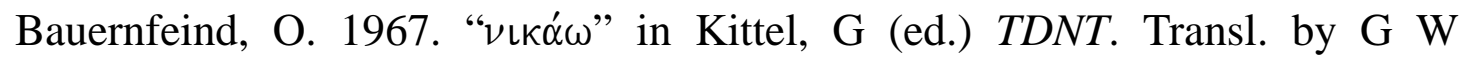
Bromiley. Vol 4. Grand Rapids: Eerdmans, 942-945.

Beale, G K 1999. The Book of Revelation: A Commentary on the Greek Text. NIGTC. Grand Rapids: Eerdmans.

Beasley-Murray, G R 1992 (1974). The Book of Revelation. Grand Rapids: Eerdmans.

Boring, M E 1986. The Theology of Revelation: The Lord Our God the Almighty Reigns. Int 40, 257-269.

-, 1989. Revelation. Louisville: John Knox Press.

-, 1992. Narrative Christology in the Apocalypse. CBQ 54, 702-723.

Botha, P J J 1988. God, Emperor worship and Society: Contemporary experiences and the Book of Revelation. Neotestamentica 22, 87-102.

Caird, G B 1966. The Revelation of St. John the Divine. London: Adam \& Charles Black.

Collins, A Y 1976. The Combat Myth in the Book of Revelation. Missoula: Scholars Press.

DeSilva, D A 1998. Honor Discourse and the Rhetorical Strategy of the Apocalypse of John. JSNT 71, 79-110.

De Smidt, J C 1994. The Holy Spirit in the Book of Revelation-Nomenclature. Neotestamentica 28, 229-244.

Duff, P B 2001. Who Rides the Beast?: Prophetic Rivalry and the Rhetoric of Crisis in the Churches of the Apocalypse. Oxford: Oxford University Press.

Du Rand, J A 1993b. Now the Salvation of Our God has come..,: A Narrative Perspective on the Hymns in Revelation 12-15. Neotestamentica 27, 313330.

-, 1997a. Johannine Perspective: Intruduction to the Johannine Writing. Midrand: Orion

Gilbertson. M 2003. God and History in the Book of Revelation: New Testament Studies in Dialogue with Pannenberg and Moltmann. Cambridge: Cambridge University Press.

Gnatkowski, M W 1989. The Implied Reader in the Book of Revelation. Th. D. dissertation. New Orleans Baptist Theological Seminary.

Gourgues, M 1985. The Thousand-Year Reign (Rev 20:1-6): Terrestrial or Celestial. CBQ 47, 676-681.

Harrington, W J 1969. The Apocalypse of St John. London: Geoffrey Chapman.

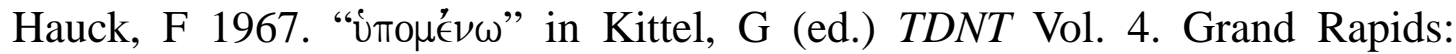
Eerdmans, 581-588.

Kistemaker, S J 2001. Revelation. Grand Rapids: Baker. 
Lee, M V 1998. A Call to Martyrdom: Function as Method and Message in Revelation. NovT 40, 164-194.

Louw, J P \& Nida, E A 1993. Greek-English Lexicon of the New Testament based on Semantic Domains. Vol 1. Cape Town: Bible Society of South Africa.

Michaels, J R 1992. Interpreting the Book of Revelation. Grand Rapids: Baker.

Moulton, W F and Geden, A S 1978 (eds.). A Concordance to the Greek Testament. 5 th ed., revised. H K Moulton. Edinburgh: T \& T Clark.

Mounce, R H 1977. The Book of Revelation. NIC. Grand Rapids: Eerdmans.

Pattemore, S 2004. The people of God in the Apocalypse: Discourse, Structure, and Exegesis. Cambridge: Cambridge University Press.

Powell, M A 1993. What is Narrative Criticism? London: SPCK.

Poythress, V S 2000. The Returning King: A Guide to the Book of Revelation. Phillipsburg: P\&R Publishing.

Reddish, M G 1982. The Theme of Martyrdom in the Book of Revelation. Ph.D. dissertation. The Southern Baptist Theological Seminary. UMI: Ann Arbor.

Resseguie, J L 1998. Revelation Unsealed: A Narrative Critical Approach to John's Apocalypse. Leiden: Brill.

Shea, W H 1985. The Parallel Literary Structure of Revelation 12 and 20. AUSS 23, 37-54.

Stevenson, G M 2001. Power and Place: Temple and Identity in the Book of Revelation. Berlin: Walter de Gruyter.

Strand, K A 1990. Overcomer: A Study in the Macrodynamic of Theme Development in the Book of Revelation. AUSS 28, 237-254.

Sweet, J P M 1979. Revelation. London: SCM Press.

Thompson, L L 1990. The Book of Revelation: Apocalypse and Empire. New York: Oxford University Press.

Uspensky, B 1973. A Poetics of Composition: The Structure of the Artistic Text and Typology of a Compositional Form. Transl. by V Zavarin \& S Wittig. Berkeley: University of California Press.

Van Eck, E 1995. Galilee and Jerusalem in Mark's Story of Jesus: A Narratological and Social Scientific Reading. Pretoria: University of Pretoria (HTS Suppl 7).

Vine, W E 1996. An Expository Dictionary of New Testament Words. Old Tappan: Fleming H Revell.

Witherington III, B 2003. Revelation. Cambridge: Cambridge University Press. 